\begin{tabular}{|c|c|}
\hline \multicolumn{2}{|r|}{ About the Journal } \\
\hline Journal DOI & https://doi.org/10.21659/rupkatha \\
\hline Journal Home & www.rupkatha.com $\oslash$ \\
\hline Indexed by & Scopus $\searrow$ Web of Science: Emerging Sources Citation Index (ESCI) DOAJ \\
\hline Journal Metrics & CiteScore 2020: 0.2 | SJR 2020: 0.162 | SNIP 2020: 0.193 | JCI 2020: 0.50 \\
\hline \multicolumn{2}{|r|}{ About the Issue } \\
\hline Themed issue & $\begin{array}{l}\text { Volume 4, number 1, } 2022 \text { (January-March) | Contemporary East and } \\
\text { Southeast Asian Literary and Cultural Studies }\end{array}$ \\
\hline Guest Editors & Dr Jeremy de Chavez $\oslash$ \& Dr Zhang Yue, University of Macau, China \\
\hline Issue DOI & https://doi.org/10.21659/rupkatha.v14n1 \\
\hline TOC & https://rupkatha.com/v14n1.php \\
\hline Peer Review & Under the responsibility of the Guest Editors \\
\hline \multicolumn{2}{|r|}{ About the Article } \\
\hline Title & $\begin{array}{l}\text { The Teleserye Story: Three Periods of the Evolution of the Filipino TV Soap } \\
\text { Opera }\end{array}$ \\
\hline Author/s & Louie Jon A. Sánchez 凶 \\
\hline Affiliation & Department of English, Ateneo de Manila University, Quezon City, Philippines \\
\hline Author ID & https://orcid.org/0000-0002-5657-7234 \\
\hline Funding & No funding received. Published free of any charge. \\
\hline Article DOI & https://doi.org/10.21659/rupkatha.v14n1.13 Pages: 1-16 \\
\hline Abstract & https://rupkatha.com/v14n113 Ø \\
\hline Full-text PDF & https://rupkatha.com/V14/n1/v14n113.pdf 囚 \\
\hline \multirow[t]{3}{*}{ Article History } & Abstract received: 5 March 2021 | Complete article received: 7 June 2021 \\
\hline & Revised article received: 24 August 2021 | Accepted: 29 August 2021 \\
\hline & First Published: 05 February 2022 \\
\hline Article Impact & Check Dynamic Impact \\
\hline Copyright & Aesthetics Media Services $\square$ \\
\hline Licensing & Creative Commons Attribution Non-Commercial $4.0 \triangle$ \\
\hline
\end{tabular}

This Open Access article is published under a Creative Commons Attribution Non-Commercial 4.0 International License (http://creativecommons.org/licenses/by-nc/4.0/), which permits non-commercial re-use, distribution, and reproduction in any medium, provided the original work is properly cited. For citation use the DOI. For commercial re-use, please contact editor@rupkatha.com. 
1 | Rupkatha Journal, Vol. 14, No. 1, 2022

Research Article

\title{
The Teleserye Story: Three Periods of the Evolution of the Filipino TV Soap Opera
}

\author{
Louie Jon A. Sánchez \\ Department of English, Ateneo de Manila University, Quezon City, Philippines
}

\begin{abstract}
The essay chronicles the history of the teleserye or the Filipino TV soap opera, one of today's transnational televisual products making waves in different parts of the globe. It covers three periods-the period of transition from radio to TV (1962 to 1986), the period of competition (1986-2000), and the period of transformation (2000-present). Traversing through 60 years of the form's enduring presence in Philippine television, it traces the format's beginnings as it was introduced to the medium in a highly volatile social environment, and assesses its continued flourishing in democratized, contemporary times and consequent entry into the highly competitive global drama market, where it serves both foreign and its very own Filipino diasporic audiences. The essay echoes the abiding thesis of my studies about the cultural history of the teleserye - that the form is indeed the drama of Filipino life. As domestic, serial form, the teleserye's intimate relation to the Filipino everyday ultimately makes it reflective of the country's life and times, its evolution interconnected with the ebb and flow of Philippine history. These are illustrated by representative texts from the said periods, as well as key contexts that unravel the evolution of the form, now gleaned from a global, aswell as diasporic context.
\end{abstract}

Keywords: teleserye, soap opera, telenovela, Asianovela, Koreanovela, Philippine television

\section{Introduction}

In this essay, I shall narrate the history of the teleserye or the Filipino TV soap opera, one of today's transnational televisual products making waves in different parts of the globe. It covers three periods - the period of transition from radio to TV (1962 to 1986), the period of competition (19862000), and the period of transformation (2000-present). This essay will traverse through 60 years of the form's enduring presence in Philippine television, beginning with its being introduced to the medium in a highly volatile social environment, up to its continued flourishing in democratized, contemporary times and consequent entry into the highly-competitive global drama market, where it serves both foreign and its very own Filipino diasporic audiences.

Histories that chronicle the development and progress of Philippine television (San Juan 1999; Maslog in Gunaratne 2000; Formoso 2001, Del Mundo 2003; and Maslog 2007) were generallychronological and relied mostly on key moments of Philippine history [i.e. broadcasting in the American period, broadcasting during and after the Second World War, broadcasting during and after Martial Law, etc.] to frame periods and narrate events. This history's periodization is no 
different. However, it selected the turning points in TV broadcasting that led to, or shaped the evolution of the teleserye, and thus were labelled as such. The periods covered still contain a similar historical zeitgeist, but the discourse assumes a generic history that also typifies seriality [in continuity], at least in three diachronic movements for this project. It begins with the period of the soap opera transition from radio to television, moves into the period of competition after Martial Law, and proceeds to an extensive period of transformation. The period of transformation is in no way terminal, as the teleserye continues to evolve. This history is a history-in-progress. Synchronically, I also look at the shifts in the dramatic form as conditioned byhistoric events and the ensuing milieu. Meanwhile, it is suggested that one reads my history of radiosoap opera in the Philippines to foreground the evolution discussed here (Sánchez 2019).

The teleserye ["tele" for television and "serye" for series] is an encompassing term that refers to all sorts of Filipino TV soap opera. It descends from early forms of serial drama introduced in radio in 1938. Then and now, it is shaped by both American soap opera conventions [in Allen (1985, 137-138): "(it is) marked by (an) absolute resistance to closure"; "(it is also) marked by (its) contemporary setting...(and) 'domestic' concerns"; "(it is) 'didactic' in nature...as (a vehicle) for consumer products"; and it is pegged as "women's fictions"], as well as Philippine narrative and dramatic traditions.

The teleserye is generally a daily fare (Mondays through Fridays), while weekly serialized forms emerge on occasion. Each episode is conventionally an hour-long, made up of the 30-minute episode proper cut down to several sets of sequences that create cliff-hangers to keep viewers hooked. The sets are interspersed with commercial placements, the necessary disruptions to the program flow. Over the years, teleseryes air in three timeslots-primetime (6 pm onwards); postnoontime show (1-2 pm onwards); and much recently, pre-noontime show (10 am to 12 noon). Theteleserye's primary language is Filipino, and pre-COVID 19 pandemic, it occupied at least 9 of the 18 total hours of broadcasting across TV networks. Traditionally catering to women and househelp, the teleserye has since found its audiences expanding, with several series targeting different segments of a once vaguely generalized range of viewers. Like the "soap opera," the word "teleserye" is often used pejoratively because of its popularity, causing it to be undervalued in academic discussions, and even in the public sphere.

It may be argued that TV drama production in the Philippines has been shaped by a "teleserye sensibility," so to speak. This means that even texts popularly called "drama anthologies" have little difference from it, in terms of story concepts, actors and acting, and production value. However, this discussion only focuses on the teleserye as an open-ended or often extended TV fiction [in contrast to drama anthology's episodic and terminal format]. Time and length may be relative, meaning, the teleserye may have run for years on end or for a more limited time. This qualification then, makes a TV mini-series eligible for a discussion as a teleserye. Nonetheless, it isthe continuing seriality of a singular or developing narrative that is key. Thus, drama anthologies are not included in this discussion. Audiences have followed several notable drama anthologies onweekend timeslots from the 1970s to the present. These however tended to present different narratives and new cast members all the time, though, admittedly, and in a few instances went for story installments, as in a mini-series. This requires further exploration and a separate discussion.

Teleseryes are structured in realism steeped in romance and melodrama-a vestige of the 
prevailing inclination of Philippine culture towards social realism. The format's intimacy to daily life makes it easy to project Filipino history and current affairs into serial narratives. In many instances, it could not help but evoke insights and ideas about the world of the audiences. Even in its eventual exploration of other themes and treatments, the teleserye's baseline setting is Philippine realia, even as characters largely inhabit other imagined worlds.

Consequently, this essay echoes the abiding thesis of my studies about the cultural history of the teleserye- that the form is indeed the drama of Filipino life, as framed by the germinal works of Soledad Reyes (1982) and Resil Mojares (1983) on the Filipino novel, and Doreen Fernandez (1996)on Filipino drama. As domestic, serial form combining the elements of the Filipino novel and drama, the teleserye's intimate relation to the Filipino everyday ultimately makes it reflective of thecountry's life and times, its evolution interconnected with the ebb and flow of Philippine history. These claims will be further illustrated by a reading of representative texts from the said periods, as well as key contexts that unravel the evolution of the form, now gleaned from a global, as well asdiasporic context.

\section{Period of Transition}

The Period of Transition is called as such for two reasons. On the one hand, it covers the time of the soap opera's adaptation into televisual form, at a juncture when television is about to grow into a burgeoning industry, an extension of its predecessor, radio. On the other hand, "transition" also refers to the country's tumultuous shift into full independence, which greatly shaped the televisual medium and its consequent products like the soap opera.

At large, this period stands on the success of the soap opera on radio, first introduced in 1938 (Enriquez 2008, 117). As investments in television in the 1950s came mostly from owners of radio stations, the newly-introduced audio-visual broadcast medium was largely seen as an expansion of mass communication interests formative of public opinion and consumption, like newspaper and magazine publishing. The period saw the growth of what was called by Del Mundo Jr. (2003) as "trimedia companies" (9), or strings of radio, TV, and newspaper conglomerates owned mostly by oligarchic families who maintained business interests while participating in politics. ${ }^{i}$ Media entities were then very important to protect their interests.

Like radio, TV was introduced to the country by Americans. The first to gain a broadcast license from the government was James Lindenberg, who established Bolinao Electronics Corporation (BEC) in 1950 (Del Mundo Jr. 2003, 6-7). BEC will later be renamed Alto Broadcasting System (ABS) in 1953, after being bought by the brother of Philippine President Elpidio Quirino (ibid). In 1957, it was acquired by the Lopezes, a prominent political family, and merged with their Chronicle Broadcasting Network (CBN) to become ABS-CBN (ibid, 8-9).

In the middle of an intensifying competition in 1962 , where musical variety and game shows lorded over the airwaves, ABS-CBN launched the first TV soap opera, Hiwaga sa Bahay na Bato (Mystery at the Stone House) a gothic-themed daily primetime drama featuring a hunchback who terrorizes a family in a heritage home in the countryside (Rodrigo 2006, 86). Radio drama stalwart Jose Miranda Cruz was tasked to adapt the form into TV. As recording technologies were scant, the soap aired live from a studio utilizing a one-camera set up. It ran for a year. Cruz made other soap 
operas and even films in the next two decades.

Two years after, in 1964, another similarly broadcast soap opera aired in pre-primetime Sundays, Santa Zita and Mary Rose (Reyes 2010; Reuter 2008; and Francisco 2002). The drama tackled the lives and struggles of a group of househelpers serving an upperclass household in the city. At the center of the series is the devotion to the Italian Saint Zita of Lucca, the Catholic patron saint of househelpers. The soap's clear didactism inspired it to constantly break the show's fourth wall to address audiences, mostly househelpers, about the episode's morals. It aired for more than a decade.

Both Hiwaga sa Bahay na Bato and Santa Zita and Mary Rose blazed the trail for the initial growth of the format on television. They embodied two formative soap opera sensibilitiesfor Hiwaga, the radio sensibility, popular for its bombastic aural attributes and shaped by conventionsand traditions honed from the precursor medium; and for Santa Zita, the theatrical sensibility, morerefined and restrained by the theater training of its founders. Unfortunately, the growth was stalled by the rise of the authoritarian regime of Ferdinand Marcos. Aside from curtailing basic civil liberties and silencing critics, the regime took over businesses including mass media. As Marcos consolidated his power through the declaration of Martial Law in 1972, allegedly to quell destabilization by opposition forces led by Communists, he closed down trimedia companies and eventually distributed what it acquired to cronies or business and political associates. These included ABS-CBN, whose owners used to be a political ally but eventually became one of Marcos'staunchest critics and arch-enemies.

Commentators lamented how dictatorial control severely constrained the once bustling TV industry (Lumbera 1976, 181; Barican-Tupas in Del Mundo Jr. 1986, 238). Suppression affected content, which prioritized Marcos propaganda (Del Mundo Jr. 2003, 16). TV also relied heavily on imported canned programs from the US as it continued operations. US canned programs of various formats were way cheaper and usually sure-fire hits when introduced in the Philippine market. Local drama production leaned towards drama anthologies which showcased original episodic concepts and even adaptations of literary works by Filipino writers.

Meanwhile, soap opera productions during this period were mostly handled by blocktime producers who bought airing rights from TV networks and raised advertising to cover production costs. Block-timing has been a constant practice even during the form's radio days, and especially during this period when network television was yet to emerge. Blocktime producers carried on with the transition of the form, bringing to televisual life many radio classics like Gulong ng Palad(Wheel of Fortune), the country's most successful transmedia soap opera, having traversed not only television but also film. It even found an afterlife in a 2003 TV reboot, as well as another film version, as of this writing.

Gulong ng Palad, a daily radio hit in 1949, was penned by Lina Flor (Reyes 2012, 346-371). Astory of star-crossed lovers being hindered from being with each other by changing fates, their social standing, and the people around them, it was adapted into weekly primetime television in 1977 by Flor's sister, Loida Flores-Viriña. The show had a very melancholic tenor, often tackling domestic and community concerns. In dramatizing the long and winding romance of the protagonists, the series reiterated the axiomatic thesis of its equally popular theme song: that life is a wheel of fortune, and it turns. Suffering passes, as in perhaps, the entire nation's suffering under 
state suppression. The show was shot from a studio in a one-camera set-up. It aired Friday nights at Banahaw Broadcasting Corporation (BBC), a crony network that took over the facilities and frequency of ABS-CBN. The series ran until 1983, and ended with a fondly-remembered grand wedding ceremony (Martin 2006, 66-79).

Notable limited-run series also emerged during the period like Malayo pa ang Umaga (Morning is Still Far, 1979), an adaptation of a Second World War-themed novel, Without Seeing the Dawn by Stevan Javellana. However, the six-year run of Gulong ng Palad became the temporal norm for many series during this period. Like their radio predecessors which also ran on that average, TV soap operas during Martial Law also fed the public with epical pathos and melodrama, a subtle social allegory, often featuring female characters who were maltreated by antagonists, reducing them to maudlin tears.

In 1978, Radio Philippines Network (RPN), another crony network, introduced the daily, pre-primetime Flordeluna, the story of a young girl of the same name, daughter of a military man, a widower. The soap, which ran until 1984, narrates the character's being mistreated by her stepmother while her father is out on military duties. Two years after, in 1980, Greater Manila Area Radio-TV Arts (GMA; later Global Media Arts Network) launched the series' competition, Anna Liza, the story of another young girl of the same name, who is kidnapped as a child and raised by awoman who despises her. Both were shot in one-camera set up, and within the confines of studios. Both were also adaptations from radio dramas from the Visayas region of central Philippines (Enriquez 2003, 23; Rodrigo 2006, 86).

The young actresses playing Flordeluna and Anna Liza, Janice de Belen and Julie Vega, respectively, practically blossomed in front of audiences with the long runs of their popular soaps. They also became matinee idols that gathered fanbases that followed them even in their cinematic stints. The stories of the girls they portrayed seemed to evoke public discontent, especially at the tumultuous twilight of the Marcos regime in the mid-1980s. Both series were described as capturing the "helpless mood of the times" (Santos-Concio 2017, 158). Anna Liza, however, proved to be moremoving and riveting, because of its lead actress's untimely demise, in 1985 (Villamor 2014, 247). Shewas only 16.

With the series unfinished, fans of Vega publicly mourned and went to the streets to bring her to her final resting place northeast of Manila. Footages of her burial—an unsettling punctuation of her character's long winding story-remind of street funeral protests three years earlier, in 1983, after opposition leader Sen. Benigno "Ninoy" Aquino, returning from a three-year exile in the US, was assassinated at the Manila International Airport. Contemplating on Vega's death and the street protest movements going on during this period, I am compelled to propound that the actress' passing is but a powerful social rehearsal of street movements that eventually toppled the dictatorship the following year, in 1986. This is accomplished by seemingly summoning the memory of Ninoy's funeral. The event is borne of a collective sense of loss for the young actress at her prime, and a lack of narrative closure for a soap that will never ever be resolved. Looking back, it appears to have been a sign of things to come.

\section{Period of Competition}


The fall of the Marcos dictatorship through the peaceful "People Power Revolution" in 1986 restored democracy in the Philippines. It also ushered in the redemocratization of the broadcast industry. Redemocratization enabled the Lopezes to reclaim ABS-CBN, after BBC was sequestered by the new government along with RPN and another crony network, Inter-island Broadcasting Corporation (IBC). Eventually, ABS-CBN's constant competition with GMA, the erstwhile leader in the industry during the Marcos era, created a duopoly, as each network tried to outdo each other in innovation and ratings. Thus, the use of "competition" to refer to this period.

Competition reinvigorated broadcasting as these networks also opened to more global concepts and tended to be more audience-driven than ever. In the early years of the period, ABSCBN and GMA served the public with much needed news and current affairs shows, often entertaining and sensational in approach (Rimban in Coronel 1999, 51). There were also musical variety shows, games shows, and a smattering of drama here and there. Meanwhile, as competitionintensified and started to be oriented towards vertical programming [weekly schedules per program, in contrast to horizontal programming, where shows ran in a straight schedule for a number of days], TV soap operas found itself gaining a stronghold in the post-noontime show timeslot.

After-lunch daily soap operas, like their predecessors from the Period of Transition, ran for years, and were structured in realistic romance and melodrama. They were in fact cultivated in the last decade of the Marcos dictatorship, directly connecting them to the format's traditional lineage. Most have also been shot in limited camera set ups, and within studios-with occasional forays in location shoots. However, these flourished further in the Period of Competition, as producers offered concepts that veered away from conventional female character-driven plots. Soaps such as Agila (1987-1992) and Valiente (1992-1997), both written by Gina Marissa Tagasa, another master ofthe soap opera format, showcased strong male protagonists that lent variety and yielded strong following. Looking back, these also evinced the haunting of the strongman Marcos, whose hubris may be found to be deconstructed in the series' lead characters.

Other soap operas eventually aired in late afternoons to pre-primetime, making the entire afternoon block a serial drama country. Many of these took off from the still very much sought after Flordeluna-Anna Liza story formula of coming-of-age young girls dealing with domestic struggles. ABS-CBN's Anna Luna (1989-1995) obviously alluded to both as it narrated the trials and tribulations of the protagonist who is finding her way back to her real family, after many years of estrangement from them. A modern-day Cinderella story like Anna Liza, Anna Luna had antagonists who indulged in oppressing the protagonist by making her wash piles of dirty clothes by hand. In my reading, oppression becomes a stand-in for all that besmirched the country, morally, culturally, and economically, during this volatile period of continuing political unrest, marked by several attempts at a government takeover by disgruntled sectors of the Philippine military. These have to be washed, but only by the golden-hearted.

Soon, a reconfiguration of the Flordeluna-Anna Liza formula was seen in ABS-CBN's Mara Clara (1992-1997), which top-billed two characters, the protagonist and the antagonist named Mara and Clara, respectively. They are victims of circumstances, having been swapped in the nursery as babies. Mara, the daughter of a rich couple, is raised by the mastermind of the crime and his wife in a depressed area in the city. Meanwhile, Clara indulges in the love and riches of 
Mara's real parents. This is until their paths cross and the truth is slowly, and painfully revealed. The swapping, it appears, was an act of vengeance by Clara's father against Mara's mother. They were old flames. The baby swapping trope Mara Clara introduced made a mark in popular consciousness and was repurposed in eventual soap productions.

The above-mentioned soap operas were produced by blocktimers. However, in the Period of Competition, blocktiming eventually had to give way to the growth of network television and corporatized modes of productions, which intended to air programs that fitted corporate vision and packaging. This was true for both Anna Luna and Mara Clara, whose productions were eventually acquired by ABS-CBN. Agila and Valiente meanwhile remained to be free of network control, primarily because its block time producer, also the creator of the country's longest-running noontime variety show, has maintained independence and sustainability over the years, even while moving from station to station-RPN (1979-1989), ABS-CBN (1989-1995) and GMA (1995present).

Another form of serial drama that flourished during this period is the mini-series. Two exemplary forms were noted-the historical, and of course, the melodramatic. The mini-series ran weekly or in a set number of installments, and were usually pegged as TV-movie specials. In 1988, ABS-CBN aired the Home Box Office (HBO)-produced $A$ Dangerous Life, a historical documentary drama on the last three years of the Marcos dictatorship, and the sweeping into the presidency of Corazon Aquino, Ninoy's wife (Contreras 1988, 1). The mini-series which ran for over two hours became TV staple in post-1986 Revolution television and was regularly shown during the commemoration of the bloodless revolt by various networks.

Another mini-series that tapped into Philippine history was the adaptation of national hero Jose Rizal's canonical novel Noli Me Tangere, directed by Eddie Romero and starred in by an exemplary ensemble cast. It was produced by the state's Cultural Center of the Philippines, and aired over Associated Broadcasting Corporation (ABC) in 1992 (De Guzman 1993, C6). Hailed for its production value as well, the series attempted to revive awareness about Rizal's life and works, as well as his germinal imagination of possibilities for liberation from ignorance and colonial suppression.

On the other hand, in 1998, ABS-CBN's Sa Sandaling Kailangan Mo Ako (When that Moment You Need Me Comes), became a popular weekend series portraying the lives of two young men eventually to be revealed as half-brothers, competing for the love of their father, as well as the affection of one woman. The story is accentuated by its political theme. Actress Tessie Tomas, who played Sonia Enriquez, the domineering mother of one of the half-brothers, seems to reprise in theshow the figure of Imelda, Marcos' notorious First Lady, which she also happens to play in $A$ Dangerous Life. The similarities were uncanny as she gives life to Sonia, an heiress and wife to a politician in a rural town.

The mid-1990s saw the soap opera creeping into primetime because of changing viewing behaviors. A fatigue for news [mostly bad, of course, especially at the height of the Asian Financial Crisis in 1997] led viewers to turn to series being experimentally aired in spots traditionally devoted to hour-long primetime newscasts (Iglesias 1996, C4). Forging ahead was Villa Quintana, a 1995 GMA blocktimer, which threatened to displace ABS-CBN news program TV Patro/from its ratings dominance (Gabunada 2012). Inspired by Romeo and Juliet, the soap ran until 1997 and is best- 
remembered for its proverbial tragic ending.

Villa Quintana motivated the reorganization of primetime, and the full shift of the broadcast grid into horizontal programming. However, what rocked the industry and propelled the complete soap opera invasion of the timeslot was the meteoric rise in the ratings game in 1996 of Marimar, acanned Mexican telenovela. Reportedly first offered to both ABS-CBN and GMA by Proctor and Gamble, the series was bought along with a substantial inventory of Latin American series by RPN, by this time, cash-strapped (ibid).

Marimar breathed new life to an otherwise dying TV station and introduced novelty to a public used to the meandering, long-winding narratives of soap operas. There was the illusion of aswift resolution as the series was already canned. Each episode was packed with plot revelations and twists, as well as interesting character development and on location shots that compelled nightly following.

The entire country was swept away by the story of Marimar, the country lass who lives by the sea, falls in love and marries the heir of a nearby hacienda who eventually abandons her and her child, and who avenges herself for all the abuse and maltreatment from her beloved's cruel family. The story was all too familiar to Filipinos, who share with Mexicans a common colonial past as well as centuries-old maritime trade relations. The phenomenal success of the series led RPN toinvite to the Philippines the actress who played Marimar, the Latin American superstar Thalia (Mercene 1996, 1). She visited twice to meet and greet her fans, and perform in concerts that celebrated what was then called "Marimar fever" (Gulle 1996, 17).

Not to be completely defeated, ABS-CBN and GMA began investing on importing and broadcasting Latin American telenovelas, as well as adapting what was there to learn from the the format's curious composition. For one, ABS-CBN, competed head-to-head with Marimarby tapping Mara Clara, its afternoon crown jewel. It brought the soap to primetime after downsizing its primetime news (Gatdula 1996, B20). The network improved its plot and production value, and decided to finally give the audiences its much-anticipated resolution. It may have been shortened in the process, but for a cogent reason. It needed to catch up with the pace of Marimar.

Towards the end of the 20th century, a great number of local soap operas across networks aired in primetime, alongside Latin American telenovelas. Temporally transformed by the telenovelas they competed with, these usually ran under two years, finally turning back from the interminable lengths of their predecessors. Also, network soaps deployed "love teams" or pairs of mostly young and popular actors to increase viewership through fandom. The soaps started to be shot in multi-camera set-ups, enhanced not only by emerging TV recording technologies but also by the grander, more believable locations sought by production. Marimar literally forced the Filipino soap opera out of the box.

$A B S-C B N$ was the most aggressive in reshaping the local soap opera after the telenovela shake up. Its drive for ratings made it produce what for this history are examples of how the local format successfully coopted telenovela qualities in order to be viable. Of course, Mara Clara was its transitional template, where it had drafted its succeeding productions. The network's mastery of the telenovela was eventually seen in three primetime hits, Mula sa Puso (From the Heart, 19971999), Esperanza (1997-1999), and Saan Ka Man Naroroon (Wherever You May Be, 1999-2001). 
Mula sa Puso narrates the romance of star-crossed lovers, an only daughter-heiress and a taxi driver. The antagonist, the heiress's only aunt, is a straight up telenovela villain-unpredictable, scheming, and comes with an armed gang which carries out her evil and often fatal plots. Early in the story, the aunt banishes the heiress' mother, a washerwoman who got knocked up by the affluent household's only son. Conniving with the woman the family decides that he marries instead, the aunt kidnaps the baby heiress to be raised in the US, and throws acid on the mother's face. Thegirl grows up not knowing who her real mother, until her 18th year, when she begins to discover her past. Meanwhile, Esperanza is the story of a young woman who against all odds strives to bring her family together earlier estranged by tragedy. Esperanza and her two siblings are raised by different families, after they were separated from each other because of a bus mishap. Their paths cross when they study in the same school and become friends. Upon finding out the truth about their identities, they decide to live together to find their missing parents. They were prevented by several duplicitous characters from completing their quest. On the other hand, Saan Ka Man Narooon, inspired by a Latin American telenovela aired by ABS-CBN, tackles the story of identical triplets whose lives once again intertwine after years of separation. One of them plays the manipulator, preventing her sisters from getting a fair share of inheritance.

That these series featured "moral polarization and schematization; extreme states of being, situations, actions; (and) overt villainy" (Brooks 1976, 11), illustrates the impact of telenovelas to Filipino soap operas during this period. As in telenovelas, the female characters' serial dilemmas were heightened by opposing forces that seemed to be larger than life. Their representations however notably turned away from the conventions of meekness epitomized by soap operas before this period. They were reconfigured to become fiercer individuals, ready to take on domestic and even social concerns. This was particularly evident in Esperanza, where the titular character, in oneepisode, registered a principled stance for workers' welfare and rights in her own father's company.

\section{Period of Transformation}

The evolution propelled by the telenovela from the mid-1990s extended towards the new millennium. More telenovelas from Latin America were imported and patronized, which made Filipino dubbing a very lucrative endeavor, and eventually, a televisual norm. Meanwhile, Filipino producers continued to reinvent the local soap opera, exploring new themes and further enhancing production value through multi-camera set up and digital technology. In 2000 , still in response to the telenovela phenomenon, ABS-CBN introduced the concept of the "teleserye."

Repackaging the soap opera concept, ABS-CBN launched the first teleserye Pangako Sa 'YO(The Promise) with a promise to combine "the magnitude of a continuing series and the sophisticated artistry of filmmaking" (Sicam 2000, C5), reminiscent of what John Caldwell (1995) once described as the "programming presence and cinematic air of distinction" (18) of 1980s US televisuality. The teleserye become the synthesis of the network's close study and acculturation of the telenovela, with distinguishing qualities refashioned particularly in its temporality and plotting. In the report which first recorded the use of the teleserye concept in public discourse, Pangako Sa 'Yo's pilot episode was described as having 34 sequences, doubling the conventional number (ibid).This meant a faster narrative pace and unfolding, which enamored Filipinos to telenovelas. 
The primetime soap ran for two years.

Pangako Sa 'Yo's reworking of narrative temporality retold a familiar realistic romance and melodrama but in a refreshing way. In this case, there was not just one but two generations of starcrossed lovers, which complicated the story and lent it a longer timeframe. The characters' relations and conflicts were revealed rather elaborately as narrative painstakingly connected time past and present. Perhaps to make the narrative more evocative, the story also touched on social issues like the unfinished land reform program, dirty electoral politics, the reign of greed in business institutions, and the prevalent unequal distribution of wealth. Pangako Sa 'Yo bravely distilled Philippine realities as the lives of the characters intertwined.

The moment of the teleserye proved to be transformative, aside from the level of organic form. In hindsight, it marked a new understanding of what a TV soap opera is, in the face of an ever-changing viewership landscape. In this history, the concept of the teleserye is regarded as an important marker of the format's evolution, a high point and synthesis of flourishing brought about by the earlier Period of Competition. The term has even successfully invaded popular consciousness, transcending its marketing label origins. By 2016, its currency was observed even among diasporic Filipinos that it landed a spot in the Oxford English Dictionary's growing corpus of World Englishes (Sabillo 2016).

The teleserye's impact may also be seen in how it transformed into several other permutations. First, it tapped various sources like cinema, graphic novels locally called "komiks," and other cultural texts. Its most notable permutation was its turn to non-realistic modes, primarily the fantastic. ABS-CBN was the first to introduce the "fantaserye" in 2003 ["fanta" for fantasy and "serye" for series] through Marina, the story of young woman cursed to be a mermaid. However, it was GMA that mastered the fantastic teleserye format through its "telefantasya" ["tele" for televisionand "fantasya" for fantasy] series with its magical world-making series Mulawin (20042005) and the Encantadia (Enchanted) trilogy [Encantadia (2005), Etheria (2005-2006), Encantadia: Pag-ibig Hanggang Wakas (Encantadia: Love Until the End, 2006)], and the Encantadia reboot (2016-2017).

Mulawin narrates the world of half-men, half-birds aspiring to keep universal peace by quelling internal strife. Meanwhile, Encantadia expands and deepens the world-making introduced in Mulawin. It recounts the history of the larger kingdom where the Mulawins belong, Encantadia, and brings viewers to the present unfolding where forces of evil threaten to shatter the kingdom's peace by usurping the throne and stealing its highly-guarded four gems. These gems are under thecare of the kingdom's four warrior princesses, who come of age and fight the odds to keep their family and world from falling apart. At a time of political strife and loss of public confidence to thegovernment, the plot of usurpation and the focus on strong women intimated a social allegory. In a study by Antonio Contreras (2008), the Encantadia series was characterized as a "parallel script upon which to locate the problematic nature of [Philippine President Gloria Macapagal-Arroyo's] presidency" (1).

Around the time of the emergence of the various permutations of the teleserye, Latin American telenovelas were slowly displaced by another global drama phenomenon, series from theEast Asian block of Taiwan, China, Japan, and South Korea. Filipino audiences indulged in novel concepts and storylines that came from these countries, which offered offbeat televisual 
perspectives and brought them closer to an often disregarded Asian connection and heritage. Locally, these were called "Asianovelas" (Asian telenovelas), "Chinovelas" (Taiwanese or Chinese telenovelas), or "Koreanovelas" (Korean telenovelas), still calling to mind the formative encounter with Latin American soaps. These Asian series proved to be decisive in how teleseryes further evolved in the Period of Transformation.

The most patronized among the Asian soap formats is the Koreanovela. It pulled at the heartstrings of Filipino viewers who delighted in romance and melodrama [especially in Stairway to Heaven (2003-2004), Full House (2004), and My Name is Kim Sam Soon (2005)]. The South Korean worldview and purview also lent a divergent but nevertheless stimulating sense of history and culture in the narrative [as in the period series Dae Jang Geum (2003-2004) and Jumong (20062007)]. The Koreanovela may often tend towards a tragic, ambiguous, or unpredictable ending [as in the Endless Love tetralogy (Autumn in My Heart, 2000; Winter Sonata, 2002; Summer Scent, 2003; and Spring Waltz, 2006) and Lovers in Paris (2004)], but it presented tropes familiar to Filipinos like coming of age, familial love, individual and social integration.

GMA was the most aggressive in Koreanovela importation and programming during this period. Aside from introducing the term "Koreanovela" (K-Drama: A New TV Genre with Global Appeal 2011, 14) it also created serial dramas shaped by what I once called the "Korean turn" in TV productions (Sanchez 2014). The most notable were the two period series about the lives and works of Philippine national heroes Andres Bonifacio and Rizal, Katipunan (The Secret Society, 2013) and I/ustrado (The Enlightened, 2014), respectively; and the pre-colonial Filipino folk-magic realism series Amaya (2011), a high-budget "epic serye" (epic series). All three tackled the issues of identityand heroism in the midst of various conditions of suppression.

GMA too, was boldest in its exploration of sensitive themes, like queer representation, in the conservative but evolving form of the teleserye. In 2013, amidst lukewarm reception from advertisers and criticism from the Catholic Bishop's Conference of the Philippines (Agting 2013), itaired in primetime My Husband's Lover, an infidelity series involving a heterosexual couple and thehusband's gay old flame. It was followed by the primetime series The Rich Man's Daughter, in 2015, an exploration of lesbian love and coming of age; and the post-noontime series Destiny Rose, in 2016, this time about the struggles of a transgender woman. The shows boosted LGBTQIA+ representation in Philippine television, where it was for many years almost absent, or diluted into stereotypes or comic relief. These shows became a platform for the nuanced dramatizations of queer experiences, inspiring renewed awareness and advocacy.

In the post-noontime show timeslot, the soap opera bailiwick, GMA maintained a stronghold through the blocktimer-produced Daisy Siete [a play on the Filipino word for "seventeen," which connotes youth and vibrance], a series headlined by the iconic popular girl dance group Sexbomb Dancers and other guest stars. The series ran for seven years, at some pointon a weekly, but generally on a daily basis, from 2003 to 2010, the longest so far in this period. In 26 seasons, the show earnestly tackled serial stories of friendship, romantic love, family, labor migration, and gender, as experienced by the characters of the down-to-earth and relatable girl group.

For its part, $\mathrm{ABS}-\mathrm{CBN}$ evolved its brand of teleseryes by skillfully reinventing and polishing realistic romance and melodrama templates, keeping their run for under two years [save for a few 
exceptions], and conquering untapped sections of the grid like the pre-noontime show timeslot. Inpre-noontime, the most successful was the romance-comedy Be Careful With My Heart (20122014), a rags-to-riches story of an aspiring flight attendant who ends up being a nanny to three rich children. This is after she was scammed by an illegal recruiter who promised a job for her abroad. In the process, she evolves a romance with the father of her wards, a widower airline tycoon. In here, the trope of the nanny-master romance beloved to Filipinos was repurposed to offer a narrative of social mobility and resilience amidst a spate of natural and man-made calamities [likesupertyphoon Haiyan in 2013] and economic uncertainty.

The network also benchmarked rarely explored themes and treatments, attributable to the expanding exposure of Filipino audiences to Koreanovelas, among other global dramas. These themes include police procedural [Basta't Kasama Kita (As Long As You're Beside Me, 2003-2004)]; horror and gothic (Spirits, 2004-2005; The Killer Bride, 2019-2020); feel-good, didactic, or pedagogical [May Bukas Pa (There is Still Tomorrow, 2009-2010); 100 Days to Heaven (2011)]; localization or adaptation of foreign franchises [the Moonstone fantasy trilogy (Lobo, The SheWolf/The Last Sentinel, 2008; Imortal, Immortal, 2010-2011; and La Luna Sangre, The Blood Moon, 2017-2018); and Two Wives, 2014-2018]; high-drama (The Greatest Love, 2016-2017), health advocacyand social commentary (Dok Ricky, Pedia, Doctor Ricky, Pediatrician, 2017-2020), among others. Note that most of these engaged in refracting current affairs as they dramatized quotidian experiences and exciting character exploits.

Among the lot, three teleseryes proved to be the most notable: Bridges of Love (2015), Ang Probinsyano (The Country Cop/Brothers, 2015-present), and On The Wings of Love (20152016). Therealistic romance and melodrama Bridges of Love is the story of two brothers estranged from each other as children, but whose paths cross once more as ambitious adults in the world of the construction business. They compete with each other until their shared past is unfurled by their interest in winning the affection of one woman. The undercurrent of the plot is vengeance, furthercomplicated by incursions into corporate drama, subtle queer politics, and critique of corruption in public works.

Meanwhile, Ang Probinsyano, an adaptation of an iconic police action flick, narrates the story of a country policeman who finds himself thrust in a crusade against lawless elements of society. He gets embroiled in several police cases in the process of finding justice for the death of his identical twin brother, a city cop. Apparently, the killers are also members of the police force deeply entrenched in a complex web of crime syndicates, primarily powered by money from illegal drugs trade. The narrative curiously became resonant of incumbent Philippine President Rodrigo Duterte's war against illegal drugs, which proved to be bloody and targeted mostly the poor, after he assumed power in 2016. Nowadays, it tackles the issue of government ascendancy and legitimacyas the very crime syndicate the protagonist has been chasing for years is now in the reins of powerand is out to get him and his sympathizers. The Duterte government, which effectively shutdown ABS-CBN at the height of COVID-19 lockdowns in the country midway of 2020, after it pushed Philippine Congress not to grant its broadcast franchise renewal franchise for personal vendetta [the network was critical of Duterte's programs, like the drug war], appears to be alluded to by theseries' running conflict.

Finally, On the Wings of Love is a romance-comedy series that follows a young woman in 
search for her mother, an immigrant in the US who mysteriously walks out on her family. Like many Filipinos, she also pursues the proverbial American dream. While in the US, she is introduced to a young man, a Filipino-American with whom she is arranged to marry. She initially engages with him for her to easily secure a green card, and they eventually fall for each other. The young man, unfortunately is the cousin of her suitor back in Manila. The love triangle ensues as she continues to seek her mother, whom she discovers as already sharing a new life with another husband, a man who rescued her from her troubles as an illegal migrant. Finding forgiveness in her heart, as well asclosure, the young woman pursues her dreams, and eventually chooses to commit, this time for real, to the man with whom she was betrothed for practical purposes, an ending optimistic enough but vastly dissimilar to the struggles of many Filipinos in multicultural America.

\section{The Teleserye Today: A Conclusion}

Another aspect that shows the teleserye's transformative impact is its jumpstarting the Filipino TV serial narratives' participation in the global drama market. Pangako Sa ' $Y o$ is in itself a showcase. Since its release in 2000, it has been imported to countries in the Southeast Asian region and other parts of the globe (Valisno 2012). Audiences from Africa were reported to have grown fondly of its protagonists (Lawrence 2015; Diamante 2016). It also rated in a number of countries in Latin America, along with other teleseryes (Cerezo 2021). In 2015, a local Cambodian television network produced an adaptation of the series ("7 PH soap operas that made waves in Southeast Asia," 2017).

Several other ABS-CBN series followed suit, and soon enough, GMA also began circulating its homegrown series around the world (Cerezo 2021). Both ABS-CBN and GMA own international TV arms that cater, primarily, to Filipino audiences in the diaspora. This makes teleserye distribution a logical and sustainable business endeavor. On the other hand, catering to other markets expanded their global reach, making Filipino drama and culture visible in the world stage. The expansion may be considered as having paved the way for a greater reach, especially as the entire world is turning to streaming platforms and a more digital viewership. Teleseryes now compete in the global platform of Netflix, among other streaming providers (Anarcon 2020).

In the end, the teleserye story is more than a history of a format, a generic evolution begotten by the TV industry and framed by the televisual medium. In representing conflicts and closures of fictional characters, it also reflected social realities for Filipino viewers to see, ruminate on, and hopefully, to act or enact upon. The teleserye story is the drama of the Filipino, a cultural practice and a form of popular culture closely intertwined with the country's history over the past six decades. It may be interesting to read similar histories to be written about the format from the different parts of the Southeast Asian region.

Histories of cultural texts like this one on the teleserye participate, not only in emphasizing the importance of popular cultures in society and everyday life, but also in locating parallel and converging points of discussion on the practices and dissemination of popular cultures in the regional and global scale. As texts like the teleserye are circulated more and more transnationally, histories like this also aid in comparative engagements that create a broader discourse that accounts, not only for their synchronic and diachronic formations, but also for their continuing 
evolution while in dialogue with other global drama texts and the larger global popular cultures shaping contemporary production, circulation, and reception.

\section{Declaration of Conflict of Interests}

The author(s) declared no potential conflicts of interest.

\section{Funding}

No funding has been received for the publication of this article. It is published free of any charge.

\section{Endnote}

' Regarding the history of oligarchy in the Philippines, see McCoy, A. (Ed.) (1994). An Anarchy of Families:State and Family in the Philippines. Quezon City: Ateneo de Manila University Press.

\section{References}

"7 PH soap operas that made waves in Southeast Asia." (2017, November 14). Rappler.com. https://www.rappler.com/entertainment/popular-filipino-teleseryes-asia-asean-summit-2017philippines.

Agting, I. (2013, June 24). "'My Husband's Lover' under CBCP scrutiny." Rappler.com. https://www.rappler.com/entertainment/my-husbands-lover-cbcp-govt.

Allen R. (1985). Speaking of Soap Operas. Chapel Hill: The University of North Carolina Press. Anarcon, J. (2020, April 4). "13 Pinoy teleseryes to binge-watch while on home quarantine." Philippine

Entertainment Portal.ph. https://www.pep.ph/guide/tv/150599/13-pinoy-teleseryes-to-binge-watch-homequarantine-streaming-apps-a724-20200404-Ifrm.

Caldwell, J. (1995). Televisuality: Style, Crisis, and Authority in American Television. New Brunswick: Rutgers University Press.

Cerezo, A. (2021, March 1). "Pinoy teleseryes are making it big in Latin America-and here's why" Philippine Star Life.com. https://philstarlife.com/geeky/373546-popular-pinoy-teleseryes-latin-america.

Coronel, S. (Ed.) (1999). From Loren to Marimar: The Philippine Media in the 1990s. Quezon City: Philippine Center for Investigative Journalism.

Contreras, A. (2008). "Female Warriors in GMA TV Fantasy Programs vis-à-vis the Fantasy Wars of GMA the President: Reflections on Simulated Women Engaged in Simulated Violence." Ideya, 9 (2). pp. 1-12.

Contreras, M. (1988, December 12). "'Dangerous Life' draws mild response." The Manila Chronicle, pp. 1. De Guzman, S. (1993, June 5). "'Noli Me Tangere' TV series airs—finally," Philippine Daily Inquirer, pp. C6. Del Mundo Jr., C. (Ed.) (1986). Philippine Mass Media: A Book of Readings. Manila: Communications Foundation for Asia.

Del Mundo Jr., C. (2003) Telebisyon: An Essay on Philippine Television. Manila: Cultural Center of the Philippines. 
Diamante, D. (2016, August 20). "Filipino soap operas a hit in Sierra Leone." Inquirer.net. https://globalnation.inquirer.net/143036/filipino-soap-operas-a-hit-in-sierra-leone\#ixzz6wzTPlyAc.

Enriquez, E. (2003). Radyo: An Essay on Philippine Radio. Manila: Cultural Center of the Philippines. Enriquez, E. (2008). Appropriation of Colonial Broadcasting: A History of Early Radio in the Philippines, 1922-

1946. Quezon City: University of the Philippines Press.

Francisco, B. (2002, June 8). "Remembering 10 wholesome TV shows." Philippine Star.com. http://www.philstar.com/entertainment/163806/ remembering-10-wholesome-tv-shows.

Fernandez, D. (1996). Palabas: Essays on Philippine Theater History. Quezon City: Ateneo de Manila University Press.

Formoso, C. (Ed.) (2001). GMA Gold: Fifty Years of Broadcasting History. Quezon City: GMA Network. Gabunada Jr., N. (2011, March 21). "The First Serious Challenge to TV Patrol's Supremacy." Wednesdays With

Nic. http://wednesdayswithnic.com/2012/03/21/challenge- tv-patrols-supremacy.Gatdula, L. (1996, July 1). "Networks collide over soaps." Philippine Daily Inquirer, pp. B20.Gulle, R. (1996, August 20). "In Thalia's thrall." Today, pp. 17.

Gunaratne, S. (Ed.) (2000). Handbook of The Media in Asia. New Delhi: Sage Publications. Iglesias, R. (1996, June 25). "Why are soaps replacing primetime news?" Philippine Daily Inquirer, pp. C4.

K-Drama: A New TV Genre with Global Appeal (2011). Korea: Korean Culture and Information Service. Lawrence, J. (2015, April 29). "In Uganda, Filipino soaps are primetime darlings." Christian Science

Monitor.com, https://www.csmonitor.com/World/Africa/2015/0429/In-Uganda-Filipino-soaps-areprimetime-darlings.

Lumbera, B. (1987). Abot-Tanaw: Sulyap at Suri sa Nagbabagong Kultura at Lipunan. Lungsod Quezon: Center for Nationalist Education.

Maslog C. (2007). Philippine Communication Today. Quezon City: New Day Publishers.Martin, M. (2006, July 1-15). "Drama is her life." Woman Today, pp. 66-79.

Mercene, R. (1996, August 21). "Thalia sends temperatures rising at Palance." Today, pp. 1.

McCoy, A. (Ed.) (1994). An Anarchy of Families: State and Family in the Philippines. Quezon City: Ateneo de Manila University Press.

Mojares, R. (1983). Origins and Rise of the Filipino Novel: A Generic Study of the Novel Until 1940. Quezon City: University of the Philippines Press.

Reyes, L. (2010, June 28). "In the name of the Father-James Reuter, SJ." Philippine Star.com. http://www.philstar.com/2010-philippine-star-24th- anniversary/596834/name-father-james-reuter-sj.

Reyes S. (1982). Nobelang Tagalog 1905-1975: Tradisyon at Modernismo. Quezon City: Ateneo de Manila University Press.

Reyes, S. (2012) Salungat: A Soledad Reyes Reader. Quezon City: Vibal Foundation.

Rodrigo, R. (2006). Kapitan: Geny Lopez and the Making of ABS-CBN. Quezon City: ABS-CBN Publishing. Reuter, J. (2008, June 7). "Drama-an Apostolate!" Philippine Star.com.

http://www.philstar.com/opinion/66434/drama-apostolate. 
16 | The Teleserye Story: Three Periods of the Evolution of the Filipino TV Soap Opera

Sabillo, K. (2016, April 16). "'Teleserye,' 'kilig' now in Oxford Dictionary." Inquirer.net. https://globalnation.inquirer.net/138647/teleserye-kilig-now-in-oxford-dictionary.

Sánchez, L. (2014) "Koreanovelas, Teleseryes, and the "Diasporization" of the Filipino/the Philippines."

Plaridel, 11 (1). pp. 66-85.

Sánchez, L. (2019) "Pagtatatag ng Tradisyon at Kumbensiyon: Ang Soap Opera sa Radyo, 1922-1963." Tomas,3 (1, 2018-2019). pp. 69-127.

San Juan, T. (Ed.) (1999). Pinoy Television: The Story of ABS-CBN. Quezon City: ABS-CBN Broadcasting Corporation.

Santos-Concio, C. (2017). My Journey: The Story of an Unexpected Leader. Quezon City: ABS-CBN PublishingInc.

Sicam, E. (2020, November 4). "ABS-CBN's 'telserye' to run for one year." Philippine Daily Inquirer, pp. C5. Valisno, J. (2012, June 15). "Pinoy TV goes international." Business World Online.

https://www.bworldonline.com/content.php?id=53472.

Villamor, E. (2014). Memory Will Remain: The Untold Story of Julie Vega. Laguna: GIML Publishing.

\section{Author's bio-note}

Louie Jon A. Sánchez is an assistant professor of English at the School of Humanities, Ateneo deManila University. 